\title{
Simulasi Perbaikan THD pada Sistem Distribusi Listrik dengan Filter Harmonisa Berbasis Software ETAP 12.6.0
}

\author{
Ojak Abdul Rozak ${ }^{1}$ \\ ${ }^{1}$ Prodi Teknik Elektro UNPAM \\ Jln. Puspiptek Raya No 46 Buaran, Setu - Tangerang Selatan 15310 \\ ojak.ardinarosultan@gmail.com
}

\begin{abstract}
ABSTRAK
Dalam upaya menghasilkan daya listrik di Industri yang berkualitas, maka diperlukan suatu pengukuran kualitas daya yang mampu mendeteksi dan memberikan informasi yang tepat untuk mengantisipasi dan mengatasi gangguan-ganguan yang terjadi. Proses pengukuran kualitas daya listrik dari 2 unit trasnformator 3000 kVA 6,3/0,4 kV sebagai catu daya ke LVDP di Industri dengan menggunakan power quality analyzer dan menganalisis hasil pengukurannya. Berdasarkan analisis hasil pengukuran, terjadi ketidakseimbangan beban yang melebihi standar ANSI C84.11995, yaitu: maksimum 6\%. Serta terjadi distorsi harmonisa yang melebihi standar IEEE 512-1992, yaitu: maksimum $5 \%$. Setelah proses analisis hasil pengukuran selesai, sebuah program simulasi peningkatan THD dibuat untuk mengurangi harmonisa dengan memasang filter harmonisa pasif jenis single tuned. Hasil simulasi setelah perbaikan (reduksi) diketahui bahwa harmonisa tegangan dan harmonisa arus mengalami penurunan hingga di bawah standar maksimum, yaitu: $5 \%$.
\end{abstract}

Kata kunci : Kualitas daya, transformator, power quality analyzer, filter harmonisa.

\begin{abstract}
Simulation Of THD Repair On Electrical Distribution System With Harmonic Filter Based On Software ETAP 12.6.0. To produce a qualified electric power in the industry, it is necessary to a power quality measurement which capable to detect and provide the right information is needed to anticipate and overcome the disturbances which will occure. Power quality measurement from is 2 units of $3000 \mathrm{kVA} 6,3 / 0,4 \mathrm{kV}$ transformer as the power supply to the LVDP in the industry using the power quality analyzer and then the measurement result are analyzed. Based on ANSI standard number C84.1-1995 in which maximum load unbalance is 6\% and harmonic distortion which is er leeding the maximum value of 5\% inrelated IEEE standard number 512-1992. Then the harmonic is anticipated by installing a signle tuned harmonic type passive filter. After the analytical process is complete, a THD improvement simulation program is created to reduce the harmonics by installing a passive harmonic type filter single tuned. From the simulation result of improvement (reduction) it is found that harmonic voltage and harmonic current have decreased and harmonics after repair is below $5 \%$.
\end{abstract}

Keywords : Power quality, transformer, power quality analyzer, harmonic filter.

\section{PENDAHULUAN}

stilah kualitas daya (power quality) adalah suatu konsep yang cukup umum dan didefinisikan sebagai penyediaan dan perancangan sistem tenaga listrik sehingga pengguna dapat memanfaatkan energi listrik dari sistem distribusi listrik (SDL) dengan baik, tanpa ada gangguan interupsi. Kualitas daya (PQ) didefinisikan di dalam Kamus Resmi IEEE 100. Persyaratan Standar IEEE sebagai suatu konsep untuk menyalakan dan mengarahkan peralatan elektronik dengan cara yang sesuai dengan pengoperasian peralatan tersebut serta kompatibel dengan sistem pengkabelan 
premis serta peralatan lain yang terhubung dengan utilitas atau mendefinisikan kualitas daya sebagai kehandalan sistem [1]. Suatu kajian cermat diperlukan berkaitan dengan penelitian sejenis yang sudah dilakukan sebelumnya, sebagai berikut:

1. Penelitian oleh Farooq, H. dkk. 2011, dipublikasikan ICREPQ, DOI:10.24084, analisis beban non linier peralatan rumah tangga menggunakan simulasi ETAP dengan percobaan tanpa alat tambahan dalam perbaikannya [2].

2. Penelitian oleh Surasmi, N. L. \& Sindhu, M.R. 2012,dipublikasikan IJETAE, ISSN: 2250-2459, analisa terhadap kondisi beban tetap harmonis menggunakan simulasi ETAP \& Genetic Algorithms serta Active Power Filter (APF) sebagai solusi perbaikannya [3].

3. Penelitian oleh Kumar, D. dkk. 2013, dipublikasikan IJSR, ISSN: 2319-7064, analisis jaringan TRANSCO GIS dengan menggunakan simulasi ETAP tanpa alat tambahan dalam perbaikannya [4].

4. Penelitian oleh Nasrul \& Firmansyah 2015, dipublikasikan IJASEIT, ISSN: 2088-5334, analisis beban non-linier: energy saving lamps (LHE), komputer, dan peralatan tenaga elektronik dengan simulasi ETAP \& pengukuran serta kapasitor aktif \& arus efektif sebagai solusi perbaikannya [5].

5. Penelitian oleh Ayunda, S.W. 2016, dipublikasikan ISJ-AJP, Vol. 3 No. 5, analisis beban non-linier: adjustable speed drives (ASD) dengan simulasi ETAP \& propagasi Matlab tanpa alat tambahan dalam perbaikannya [6].

6. Penelitian oleh Ravichandran, D. dan Panneerselvam, E.R. 2016, yang telah dipublikasikan IJCTA, Vol. 9 No. 37, analisis perangkat mitigasi menggunakan simulasi ETAP \& perhitungan tanpa alat tambahan dalam perbaikannya [7].

7. Penelitian oleh Zahran, M.H. dkk. 2016, dipublikasikan IJEIT, ISSN: 2277-3754, analisis beban non-linier: inverter \& rectifier, kompensator VAR statis dan perangkat solid state controlled dengan simulasi ETAP dan phase shift transformator $30^{\circ}$ \& two filter technique sebagai solusi perbaikannya [8].
Karena itu, dalam mengaktualisasikan hasil kajian tersebut, dirasa perlu melakukan suatu pendekatan penelitian dengan judul: "Simulasi Perbaikan THD pada Sistem Distribusi Listrik dengan Filter Harmonisa Berbasis Software ETAP 12.6.0".

Judul tersebut dipilih dengan alasan bahwa fenomena kinerja SDL kuat korelasinya dengan kualitas daya dan kehandalan sebagai objektivitas pelayanan terhadap proses produksi di Industri.

Tujuan penelitian meliputi hasil dan target yang ingin dicapai untuk memperoleh jawaban atas permasalahan penelitian yang relevan dengan identitas dan rumusan masalah serta mencerminkan proses penelitian, yaitu:

1. Untuk mengetahui ganguan-gangguan pada SDL dengan mengukur $P Q$ menggunakan Fluke 1735 Power Logger, meliputi: tegangan, arus, dan frekuensi; bentuk gelombang arus dan tegangan; spektrum harmonisa; daya serta faktor daya.

2. Dapat mendesain program simulasi $P Q$ dengan electrical transient analysis program (ETAP) Versi 12.6.0, meliputi: aliran daya (LF), analisa harmonisa (HA) dan perbaikan THD dengan filter pasif harmonisa.

3. Hasil penelitian dapat digunakan sebagai referensi dalam mengambil langkah kebijakan untuk peningkatan kualitas SDL.

\section{TEORI}

\section{Kualitas Daya}

Kualitas daya listrik sangat dipengaruhi oleh beban tak seimbang dari sistem tenaga listrik. Kualitas daya ditentukan oleh: pemadaman, faktor daya yang rendah, naik dan turun tegangan, tegangan tak seimbang, dan distorsi harmonisa saat kondisi steady state.

\section{Daya dan Faktor Daya}

Terdapat tiga besaran utama daya listrik, yaitu: semu (VA), nyata (W) dan reaktif (VAR) [9]. Daya sebagai hasil kali arus dan tegangan, sedangkan energi adalah daya dikalikan waktu, dengan asumsi bahwa banyaknya aliran listrik per satuan waktu (Joule/s). 


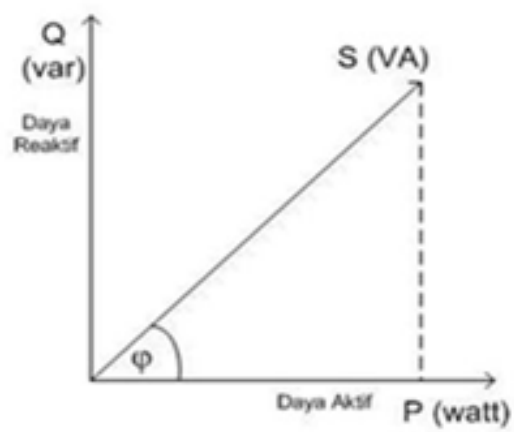

Gambar 1. Segitiga Daya [10]

Faktor daya (PF) adalah besar sudut antara daya semu (S) dan daya nyata $(P)$ akibat perubahan daya reaktif $(\mathrm{Q})$ [10].

\section{Tegangan, Arus dan Frekuensi}

Tegangan ideal yang seharusnya diterima oleh pihak konsumen adalah $220 \angle 0^{\circ}$ fasa $A$ (R/L1), $220 \angle-120^{\circ}$ fasa B (S/L2), $220 \angle 120^{\circ}$ fasa $C(T / L 2)$.

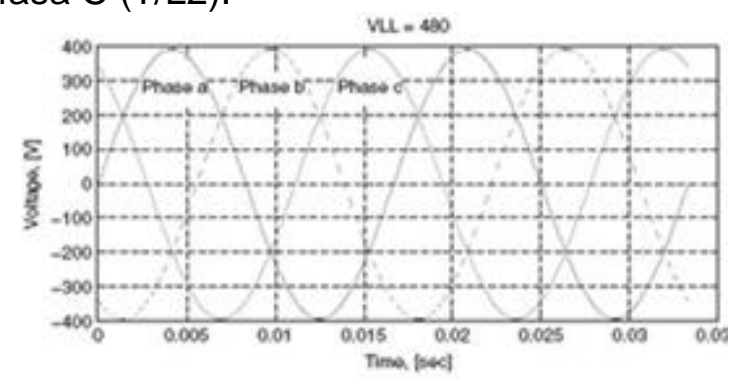

Gambar 2. Tegangan Fasa Tiga Ideal [11]

ANSI C84.1-1995, untuk tegangan sistem tak seimbang tidak boleh lebih dari $3 \%$ pada saat tak dibebani, dan maksimal $6 \%$ untuk sistem yang dibebani [9].

Saat beban penuh maksimum penurunan tegangan (SPLN: 72.1987) bagi sistem radial untuk SUTM: 5\% dari tegangan kerja, transformator distribusi: $3 \%$ dari tegangan kerja, STR sebesar 4\% dari tegangan kerja tergantung kepadatan beban, sambungan rumah: $1 \%$ dari tegangan nominal [10].

Jadi kondisi tegangan fasa tiga yang tidak seimbang terjadi baik dalam hal besar maupun beda sudut fasanya [11].

Dimana beban resistif menghasilkan $P F=1$, beban induktif menghasilkan $P F$ tertinggal (lagging) dan beban kapasitif menghasilkan $P F$ mendahului (leading). Selain itu, beban tak linier menyebabkan bentuk gelombang arus tidak sinusoidal.

Frekuensi ideal yang diterima konsumen listrik harus sudah memenuhi standar yang berlaku di Indonesia, yaitu: $50 \mathrm{~Hz}$ [9].
Jadi arus, tegangan, dan frekuensi dalam keadaan ideal sangat menentukan akan kualitas daya listrik.

\section{Harmonisa}

Berdasarkan standar IEEE 519 tahun 1992, beban tak linier digolongkan atas tiga tipe peralatan, yaitu [12]: peralatan elektronika daya; pembangkit busur api, seperti: arc furnaces, fluorescent lamp; dan peralatan yang bersaturasi inti ferromagnetik, seperti: transformator dan motor induksi.

Standar IEC 6100-2-1-1990, harmonisa sebagai arus atau tegangan sinusoidal dengan kelipatan frekuensi sistem dari pasokan tenaga listrik untuk dioperasikan dalam frekuensi $50 \mathrm{~Hz}$ atau $60 \mathrm{~Hz}$ [13].

Kerugian sistem dapat ditimbulkan oleh harmonisa saat adanya distorsi frekuensi fundamental, maka: kinerja alat menurun, panas berlebih, dan kualitas daya sistem menurun [14].

Gejala pembentukan gelombang sinusoidal dengan frekuensinya merupakan perkalian bilangan bulat dari frekuensi dasarnya atau disebut harmonisa. Jika terjadi superposisi antara gelombang frekuensi harmonisa dengan gelombang frekuensi dasarnya maka akan terbentuk gelombang terdistorsi atau tak sinusoidal.

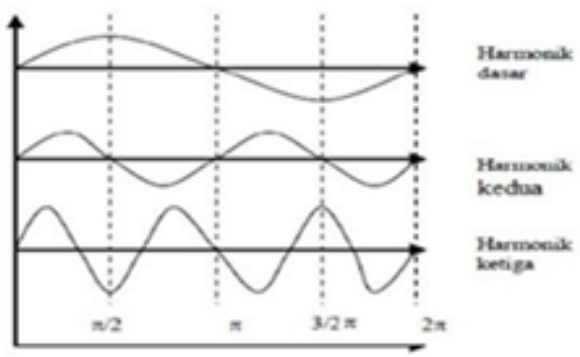

Gambar 3. Gelombang Frekuensi [15]

Urutan orde harmonisa yaitu: urutan positif: panas lebih pada konduktor/saluran, urutan negatif: torsi lawan pada motor listrik/motor berlawanan arah putar-nya, dan urutan nol: naiknya arus kontribusi pada kawat netral.

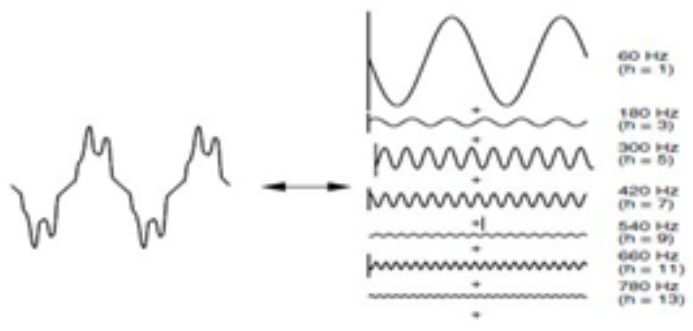

Gambar 4. Gelombang Harmonisa $60 \mathrm{~Hz}$ [16] 
Tabel 1. Urutan Fasa Harmonisa [16]

\begin{tabular}{ccc}
\hline \hline Orde Harmonisa & Frekuensi $\mathbf{( H z )}$ & Urutan \\
\hline \hline 1 & 50 & + \\
\hline 2 & 100 & - \\
\hline 3 & 150 & 0 \\
\hline dst & dst & dst \\
\hline
\end{tabular}

Interaksi antara komponen gelombang lain dengan gelombang sinusoidal akibat beban tak-linier disebut harmonisa menyebabkan cacat gelombang, komponen gelombang lain dengan frekuensi kelipatan integer dari komponen frekuensi fundamental disebut harmonisa [17]

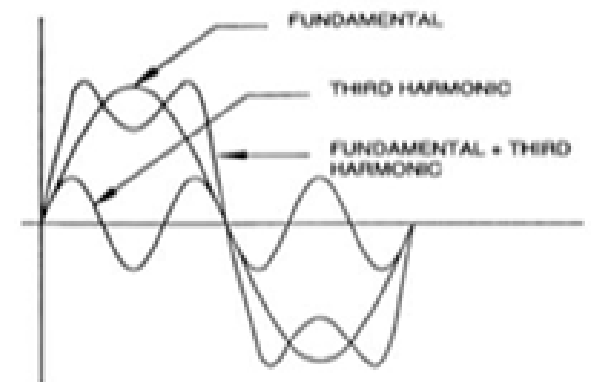

Gambar 5. Gelombang fundamental [17]

Tingkat distorsi harmonisa dalam bentuk spektrum harmonisa dengan dilengkapi besar dan sudut fase masing-masing harmonisa tunggal. Kuantitas tunggal, distorsi harmonisa total (THD), sebagai ukuran nilai efektif distorsi harmonisa [9].

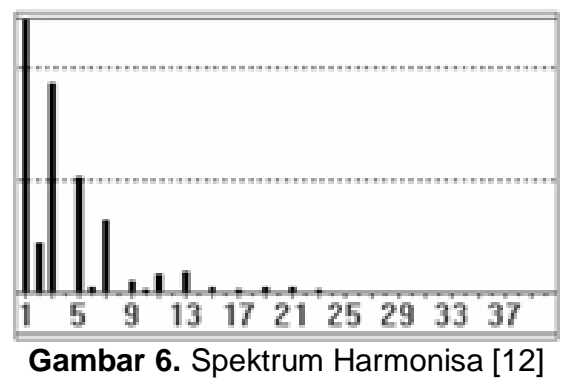

Menurut IEEE 512-1992, distorsi harmonisa tegangan bisa ditentukan oleh tegangan sistemnya sebagai batasan dan harmonisa arus ditentukan $\left(I_{S C} / I_{L}\right) . I_{S C}$ adalah arus hubung singkat pada point of common coupling (PCC) sedang $I_{L}$ adalah arus beban fundamental nominal [9].

Distorsi pada PCC yang mengakibatkan DC offset tak dibenarkan dan TDD merupakan maksimum harmonisa pada arus beban maksimum sistem tenaga listrik [19].
Sementara perbandingan nilai rms antara komponen arus harmonisa dengan arus beban demand maksimum disebut total demand distortion (TDD). pada saat beban penuh THD = TDD, maka TDD merupakan besarnya distorsi arus yang terjadi pada sistem tenaga listrik. THD yang dapat diterima jika bernilai $<5 \%$ dari tegangan atau arus fundamentalnya. jika melebihi batas tersebut, maka alat elektronik tidak boleh digunakan [20].

Tabel 2. Batas distorsi harmonisa [14]

\begin{tabular}{|c|c|c|c|c|c|c|}
\hline$b_{x} / I_{t}$ & $b<11$ & $11 \leq h<17$ & $17 \leq h<23$ & $23 \leq b<35$ & $35 \leq k$ & TDD \\
\hline \multicolumn{7}{|c|}{ Vins $69 \mathrm{av}$} \\
\hline$<20$ & 4,0 & 20 & 15 & 0.8 & 0,3 & 9,0 \\
\hline $20-10$ & 7,0 & 35 & 23 & 1,0 & 0,5 & 80 \\
\hline 50.100 & 10,0 & 4s & 40 & 1,5 & 0,7 & 12,0 \\
\hline $100-1000$ & 12.0 & 53 & 3,0 & 2,0 & 10 & 150 \\
\hline$>1000$ & 18,0 & 70 & 60 & 2.5 & 1.4 & 30.0 \\
\hline \multicolumn{7}{|c|}{$69 \mathrm{kV}<\mathrm{Va} \leq 161 \mathrm{kV}$} \\
\hline$<20^{\circ}$ & 20 & 10 & Q.7s & 03 & 0,15 & 23 \\
\hline $20=90$ & 3,5 & 1,75 & 1,25 & 0,5 & 0,23 & 4,0 \\
\hline $50-100$ & 3,0 & 223 & 2.0 & 0,73 & 0.35 & 60 \\
\hline $100-1000$ & 60 & 2,75 & 25 & 10 & 0,5 & 7, \\
\hline$>1000$ & 75 & 3,5 & 3.0 & 1.25 & 0,7 & 10,0 \\
\hline \multicolumn{7}{|c|}{$V_{b}>161 \mathrm{kV}$} \\
\hline$<50$ & 2,0 & 10 & 0,55 & 0,3 & 0,15 & 23 \\
\hline 250 & 300 & 13 & 1.15 & 0.45 & 0.22 & 3,75 \\
\hline 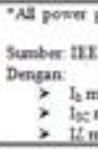 & 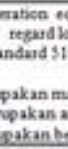 & 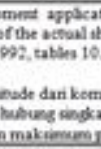 & 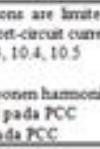 & $\begin{array}{l}\text { then } \\
\left.\text { nate } \mathrm{I}_{\mathrm{g}}\right]\end{array}$ & & tortion \\
\hline
\end{tabular}

Peralatan-peralatan dalam sistem tenaga listrik yang dapat menyebabkan terjadinya harmonisa, yaitu: konverter, tanur busur api, transformator, dan mesin-mesin listrik [14]. Harmonisa pada sistem tenaga listrik disebabkan oleh beban tak linier, yaitu: peralatan elektronika daya, seperti: mosfet, SCR, dan IGBT.

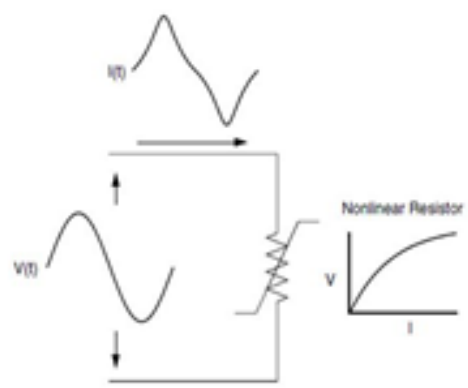

Gambar 7. Harmonisa Akibat Beban Tak Linier [16]

Sumber harmonisa terdiri dari: alat dengan kondisi saturasi (bersifat magnetik), seperti: transformator, mesin-mesin listrik, tanur busur listrik, power suplai, dan magnetic ballast; dan alat elektronika daya, seperti: thyristor, dioda; dan lain-lain [21].

Harmonisa memiliki dampak jangka pendek dan jangka panjang, sebagai berikut [15]: 
1. Dampak jangka pendek: mengganggu alat-alat kontrol pada sistem elektronik; terjadinya kesalahan pada alat-alat ukur listrik yang mempunyai prinsip induksi magnetik; menganggu alat pengaman pada sistem tenaga listrik (relai): pada mesin-mesin berputar (generator/motor), torsi mekanik yang disebabkan oleh harmonisa arus dapat menyebabkan getaran dan suara/bising pada mesinmesin tersebut serta sistem komunikasi yang berada dekat dengan sistem tenaga listrik akan terganggu oleh harmonisa.

2. Dampak jangka panjang: panas pada kabel, mesin-mesin listrik, transformator, kapasitor, dan alat lainnya.

\section{Filter pasif}

Penerapan filter pasif merupakan tahapan penyelesaian yang efektif dan ekonomis sebagai solusi masalah harmonisa. Dalam penelitian ini akan menggunakan tipe filter pasif single tuned filter yang mempunyai impedansi rendah [15].

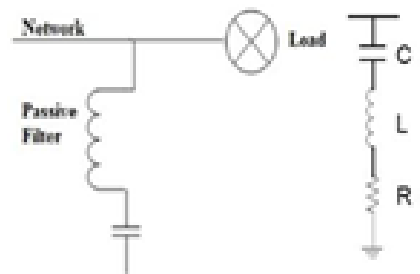

Gambar 8. Rangkain Fiter Pasif [16]

\section{Fluke 1735 Power Logger}

Langkah pertama dalam mengelola energi listrik adalah dengan memahami "berapa banyak dan kapan" energi listrik sedang digunakan. Sehingga diperlukan Fluke 1735 Power Logger.

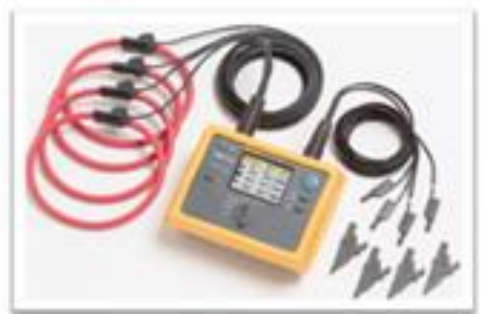

Gambar 9. Fluke 1735 Power Logger [22]

Electric transient and analysis program (ETAP) Versi 12.6.0 memiliki fitur-fitur yang berfungsi untuk berbagai analisis, yaitu: aliran daya (LF), hubung singkat (SC), motor starting, stabilitas transien, koordinasi relai proteksi, dan sistem harmonisasi.

Elemen-elemen rangkaian dan/atau jalur sistem pentanahan pada proyek sistem tenaga listrik ini dapat di-edit langsung sehingga memudahkan dalam analisis hasil perhitungan dan dapat ditampilkan.

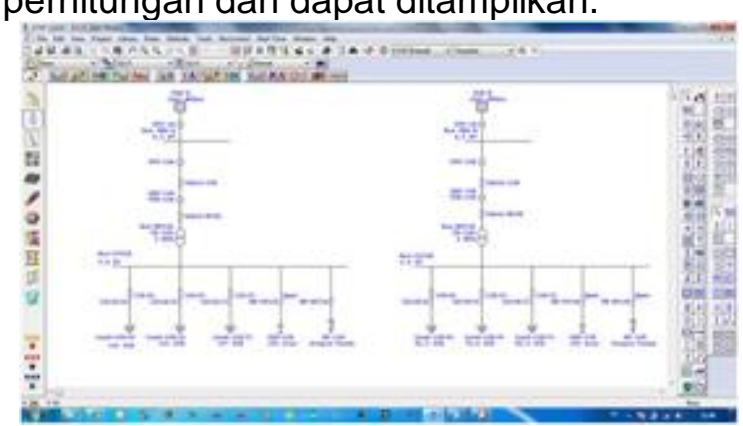

Gambar 10. Tampilan Program ETAP [27]

\section{METODOLOGI}

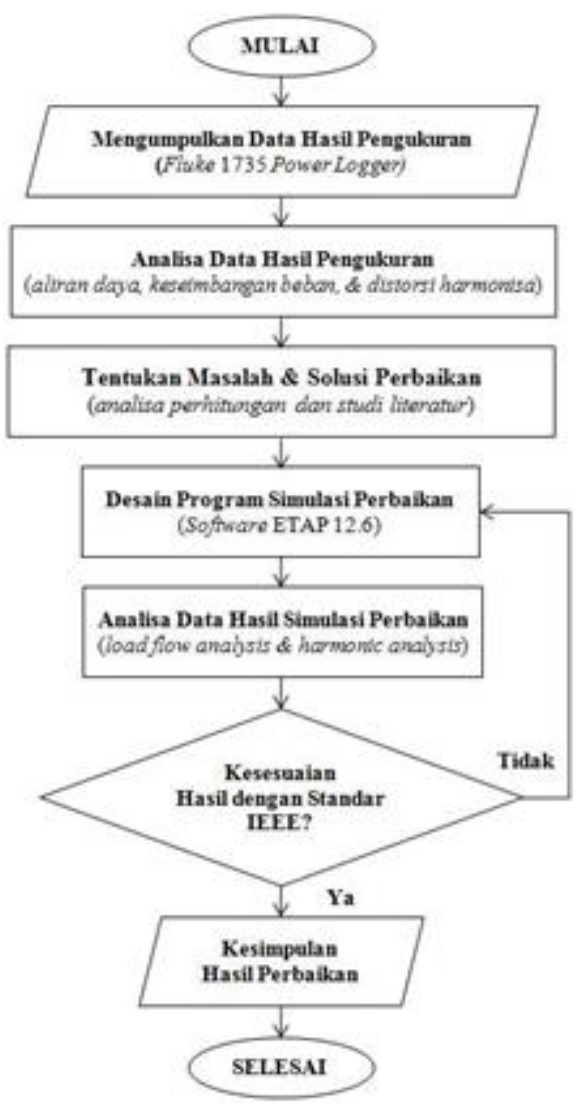

Gambar 11. Alur Proses Penelitian

Metode yang dilakukan dalam penelitian ini adalah sebagai berikut: Studi Literatur, pencarian materi-materi dan jurnal-jurnal referensi yang terkait dengan masalah penelitian; Konsultasi, untuk menentukan penggunaan metode yang sesuai dengan implementasi sistem sehingga memiliki hasil keluaran sesuai dengan tujuan penelitian; 
Pengukuran dan Perancangan Program, simulasi perbaikan, meliputi: analisis data hasil pengukuran berupa: tegangan, arus, dan frekuensi; bentuk gelombang arus dan tegangan; spektrum harmonisa; daya serta faktor daya; dan Desain Program.

\section{HASIL DAN PEMBAHASAN}

Simulasi Perbaikan THD pada SDL dengan Filter Harmonisa Berbasis Software ETAP 12.6.0 pada sisi sekunder dari 2 unit

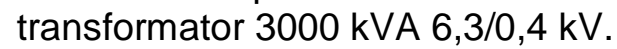

Tabel 3. Spesifikasi Trasformator

\begin{tabular}{|c|c|c|c|}
\hline \multirow{2}{*}{$\begin{array}{l}\text { ABB Transmision and Distribution Ltd. } \\
\text { Transformer Performance }\end{array}$} & UoM & A & B \\
\hline & & $\operatorname{IEC} 76$ & $\operatorname{IEC} 76$ \\
\hline Rated Voltage & (kVA) & 3000 & \\
\hline Phases & & 3 & 3000 \\
\hline Frequency & $(\mathrm{Hz})$ & 50 & 50 \\
\hline HV Amperes & (B) & 274,9 & 274,9 \\
\hline LV Amperes & (B) & 4330 & 4330 \\
\hline Conn. Symbol & & Dyn5 & Dyn5 \\
\hline Cooling Type & & \multirow{2}{*}{ ONAN } & \multirow{2}{*}{$\frac{\text { ONAN }}{6.25}$} \\
\hline Impedance at $75^{\circ} \mathrm{C}$ & (\%) & & \\
\hline Insulation Temp. Class & & $\frac{6,25}{\mathrm{~A}}$ & A \\
\hline \multirow{2}{*}{ Insul Levels (HV) } & & $\mathrm{LI} 60 \mathrm{AC} 20 / \mathrm{AC} 3$ & $\mathrm{~L} 160 \mathrm{AC} 20 / \mathrm{AC} 3$ \\
\hline & & & \\
\hline $\begin{array}{l}\text { InsulLevels (LV) } \\
\text { Winding Temp. Rise }\end{array}$ & $\left({ }^{\circ} \mathrm{C}\right)$ & 65 & 65 \\
\hline Top Oil Temp. Rise & $\left({ }^{\circ} \mathrm{C}\right)$ & 60 & 60 \\
\hline Oil Volume & (L) & 1998 & 1998 \\
\hline Untanking Mass & $(\mathrm{kg})$ & - & - \\
\hline Total Mass & $(\mathrm{kg})$ & 8080 & 8080 \\
\hline Premissible Pressure Min Max & $\mathrm{kPa}(\mathrm{abs})$ & 115 & 115 \\
\hline Tap Switch - Connection (HV/LV) & & $/ \mathrm{Y}$ & $/ \mathrm{Y}$ \\
\hline $\begin{array}{ll}\text { Position } 1 & (4-5) \\
\end{array}$ & (HV/LV) & 6615 & 6615 \\
\hline $\begin{array}{ll}\text { Position 2 } & (5-3)\end{array}$ & (HV/LV) & 6458 & 6458 \\
\hline $\begin{array}{ll}\text { Position } 3 & (3-6) \\
\end{array}$ & (HV/LV) & $\frac{6300}{/} \quad 400$ & 6300,400 \\
\hline $\begin{array}{ll}\text { Position } 4 \quad(6-2) \\
\end{array}$ & $(\mathrm{HV} / \mathrm{LV})$ & 6143 & 6143 \\
\hline $\begin{array}{ll}\text { Position } 5 & (2-7) \\
\end{array}$ & (HV/LV) & 5985 & 5985 \\
\hline Serial No. & & $89382-1$ & $89381-1$ \\
\hline Manufactured & & 1995 & 1995 \\
\hline
\end{tabular}

Gambaran dari 2 unit transformator 3000 kVA 6,3/0,4 kV dalam bentuk single line diagram dari SDL untuk Simulasi Perbaikan THD pada SDL dengan Filter Harmonisa berbasis Software ETAP 12.6.0.

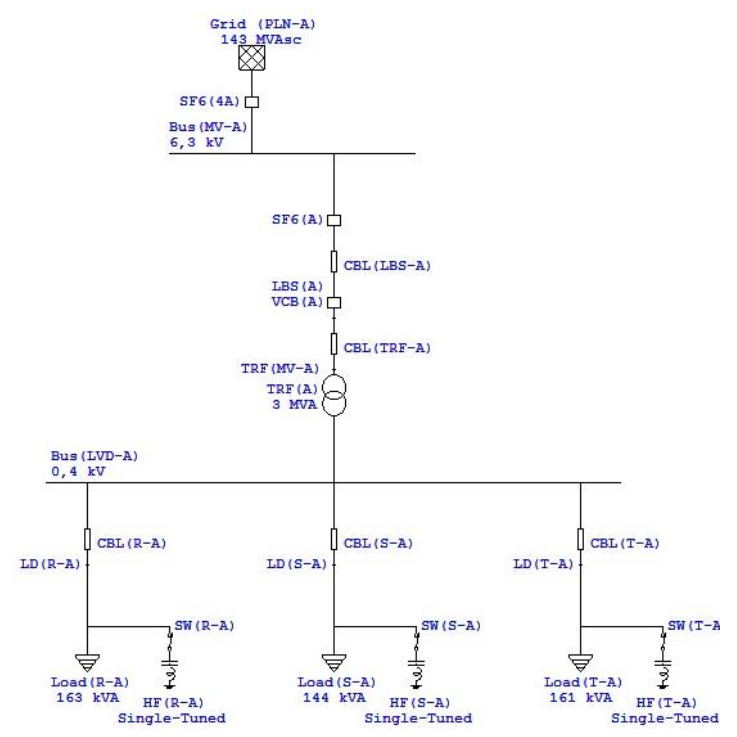

Gambar 12. Single line diagram SDL trafo-A

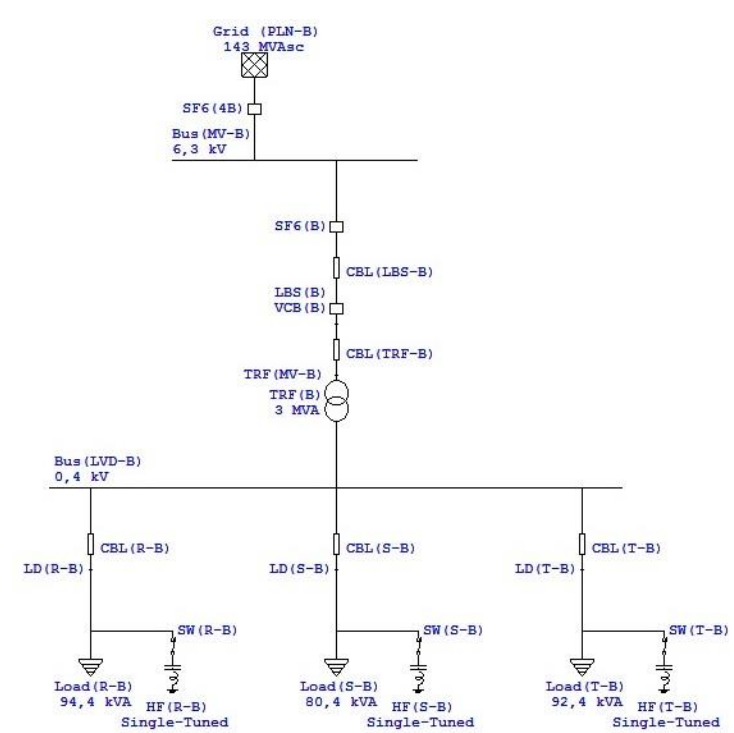

Gambar 13. Single line diagram SDL trafo-B

\section{Hasil Pengukuran}

Hasil pengukuran PQ dari 2 transformator menggunakan Fluke 1735 Power Logger, terdiri dari pengukuran:

1. Tegangan, arus dan frekuensi

Tegangan $\left(223,7 V_{\text {rms }}\right)(50 \mathrm{~Hz})$.

Arus setiap fasa ada trafo line-A:

$\left(\mathrm{R} / \mathrm{L} 1=0,757 k A_{r m s}\right),\left(\mathrm{S} / \mathrm{L} 2=0,660 k A_{r m s}\right)$,

$\left(\mathrm{T} / \mathrm{L} 3=0,742 k A_{r m s}\right)$.

Arus untuk setiap fasa pada trafo line-B:

$\left(\mathrm{R} / \mathrm{L} 1=0,429 \mathrm{kA} A_{\mathrm{rms}}\right),\left(\mathrm{S} / \mathrm{L} 2=0,372 \mathrm{kA}_{\mathrm{rms}}\right)$,

$\left(\mathrm{T} / \mathrm{L} 3=0,420 \mathrm{kA}_{\mathrm{rms}}\right)$.

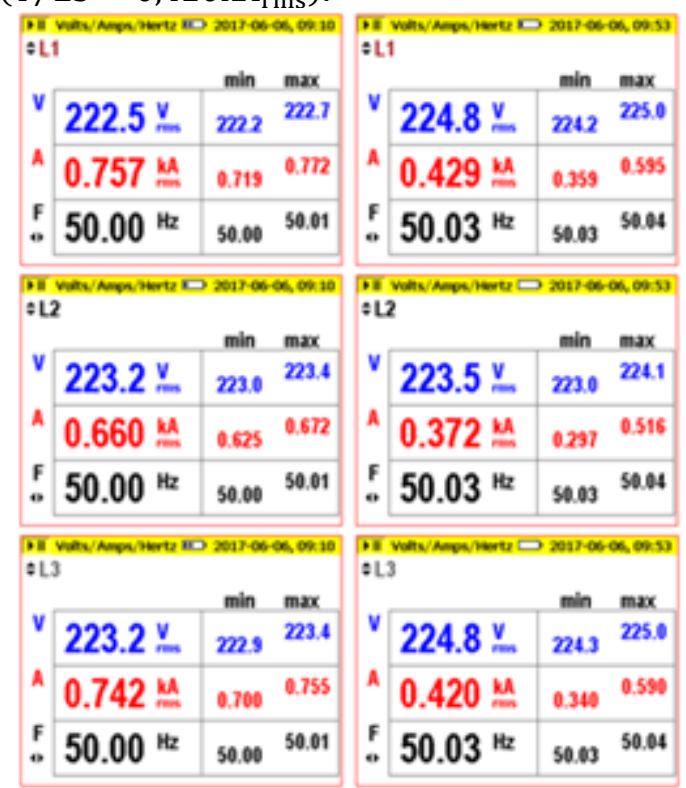

Gambar 14. VAF Trafo

Bentuk gelombang tegangan (V) dalam keadaan sinusoidal (ideal), sementara bentuk gelombang arus (A) dalam keadaan tak sinusoidal (tidak ideal). 
Dengan demikian telah terjadi ketidakseimbangan beban dan ada gangguan pada sisi arus $(A)$.

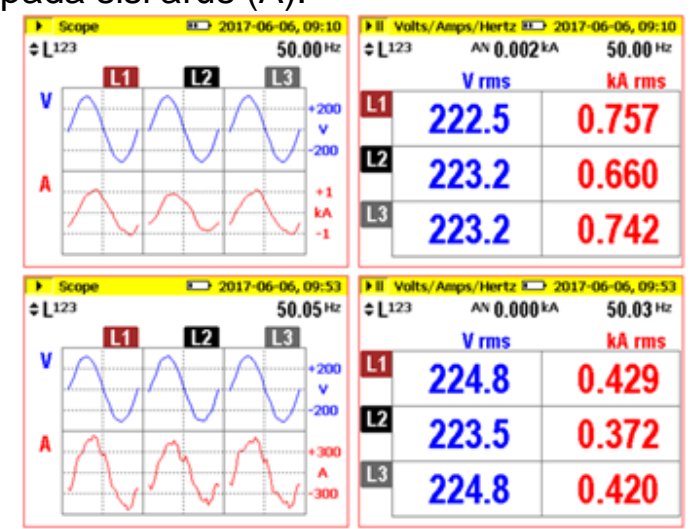

Gambar 15. Gelombang VA Trafo

2. Daya dan faktor daya

\begin{tabular}{|c|c|c|c|c|c|c|c|}
\hline \multirow{2}{*}{\multicolumn{2}{|c|}{$\begin{array}{c}\text { Dil Power } \\
=L^{123} \quad 409.3_{\text {tot }} \\
\mathrm{kW}\end{array}$}} & 2017 & $06-06,00: 11$ & DII $\mathrm{R}$ & ower & 2017 & $66-06,00: 11$ \\
\hline & & $\begin{array}{l}486.9_{\text {tot }} \\
\mathrm{kVA}\end{array}$ & $\begin{array}{l}0.839_{\text {tot }} \\
\text { PF - }\end{array}$ & $\because L^{12}$ & $\begin{array}{l}{ }^{409.3_{\text {tot }}} \\
\mathrm{kW}\end{array}$ & $\begin{array}{l}486.9_{\text {tot }} \\
k V A\end{array}$ & $\begin{array}{l}261.2_{\text {tot }} \\
\text { kvar o }\end{array}$ \\
\hline & 137.8 & 170.8 & 0.806 & L1 & 137.8 & 170.8 & 101.3 \\
\hline & 123.6 & 148.9 & 0.829 & L2 & 123.6 & 148.9 & 82.1 \\
\hline L3 & 147.9 & 167.2 & 0.884 & [13 & 147.9 & 167.2 & 77.8 \\
\hline $\begin{array}{l}\text { P } \\
12\end{array}$ & $\begin{array}{l}{ }^{3} 249.7_{\text {tot }} \\
\mathrm{kW}\end{array}$ & $\begin{array}{l}202017 \\
273.4_{\text {tot }} \\
\text { kVA }\end{array}$ & $\begin{array}{c}06-06,10: 07 \\
0.907_{\text {tot }} \\
\text { PF of }\end{array}$ & $\begin{array}{l}P 11 \text { P } \\
=L^{12}\end{array}$ & $249.7_{\text {tot }}$ & $\begin{array}{l}20017 \\
273.4_{\text {tot }} \\
\mathrm{kVA}\end{array}$ & $\begin{array}{r}16-0,10: 07 \\
88.2_{\text {tot }} \\
\text { kvar - }\end{array}$ \\
\hline $\mathbf{L}$ & 87.1 & 97.0 & 0.893 & 1 & 87.1 & 97.0 & 36.8 \\
\hline L & 75.0 & 83.1 & 0.896 & 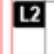 & 75.0 & 83.1 & 29.0 \\
\hline L3 & 87.6 & 93.3 & 0.934 & L3 & 87.6 & 93.3 & 22.4 \\
\hline
\end{tabular}

Gambar 16. Daya dan PF Trafo

Average dari faktor daya ( $P F=84,0 \%$ ) dan summary daya trafo line-A, yaitu: $(P=409,3 \mathrm{~kW}), \quad(S=486,9 \mathrm{kVA}), \quad(Q=$ 261,2 kVAR)

Average dari faktor daya ( $\mathrm{PF}=90,8 \%$ ) dan summary daya trafo line-B, yaitu:

$(P=249,7 \mathrm{~kW}) \quad, \quad(S=273,4 \mathrm{kVA}) \quad, \quad(Q=$ $88,2 k V A R)$

3. Spektrum Harmonisa

Hasil pengukuran orde ke $(h)$, arus orde ke $\mathrm{h}\left(I_{h}\right)$, arus fundamental $\left(I_{1}\right)$, dan arus distorsi harmonisa total $\left(T H D_{i}\right)$ pada setiap fasa dari trafo (lihat Gambar 17), dimana:

a. Trafo line-A:
1) Fasa $R / L 1$ :
$h=5\left(I_{1}=0,754 k A\right) \quad\left(T H D_{i}=5,3 \%\right)$.
2) Fasa $S / L 2$ :
$h=5\left(I_{1}=0,653 k A\right)\left(T H D_{i}=11,1 \%\right)$.
3) Fasa T/L3:
$h=\left(I_{1}=0,738 \mathrm{kA}\right)\left(T H D_{i}=8,7 \%\right)$.

b. Trafo line-B:
1) Fasa $R / L 1:$
$h=5\left(I_{1}=0,407 k A\right)\left(T H D_{i}=9,9 \%\right)$.

2) Fasa $S / L 2$ :

$h=5\left(I_{1}=0,333 k A\right)\left(T H D_{i}=18,0 \%\right)$.

3) Fasa T/L3:

$h=5\left(I_{1}=0,382 k A\right)\left(T H D_{i}=13,5 \%\right)$

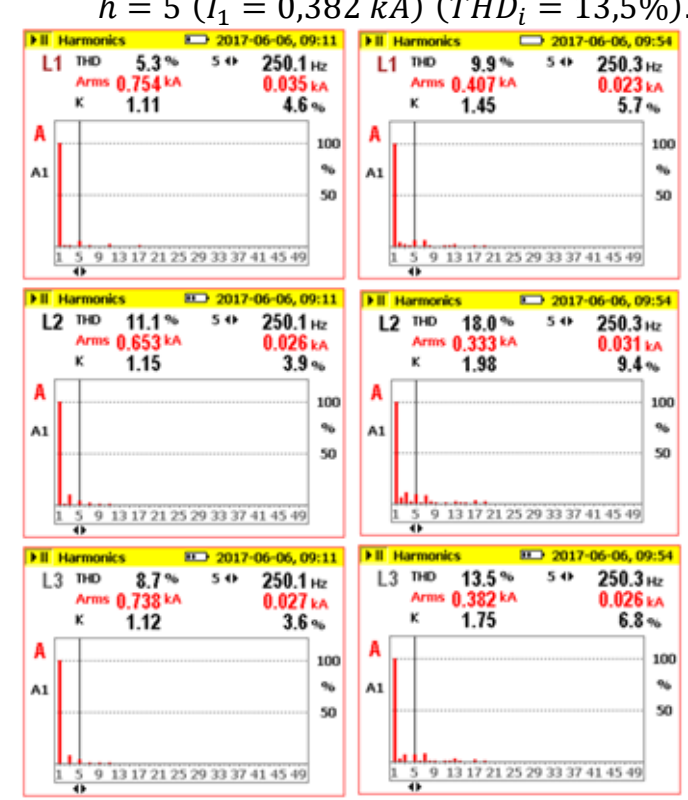

Gambar 17. Spektrum Harmonisa Trafo

\section{Hasil Simulasi Aliran Daya}

Hasil program simulasi load flow analysis (LF) sebelum perbaikan ditampilkan sebagai pembanding dari hasil program simulasi sesudah perbaikan.

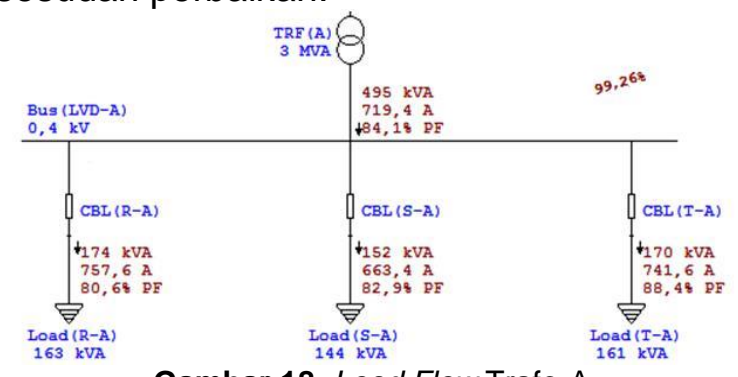

Gambar 18. Load Flow Trafo-A

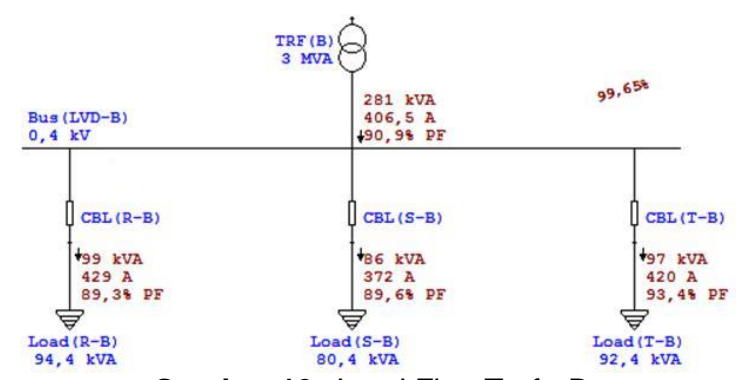

Gambar 19. Load Flow Trafo-B

Hasil simulasi software ETAP 12.6.0 pada setiap fasa dari trafo, yaitu: trafo line-A:

1. Besarnya daya pada R/L1 adalah: $(P=140 \mathrm{~kW}),(\mathrm{S}=174 \mathrm{kVA}),(\mathrm{Q}=103 \mathrm{kVAR})$.

2. Besarnya daya pada $S / L 2$ adalah: $(P=126 k W),(S=152 k V A),(Q=85 k V A R)$. 
3. Besarnya daya pada $T / L 3$ adalah: $(P=150 k W),(S=170 k V A),(Q=79 k V A R)$.

4. Besarnya faktor daya $(P F=84,1 \%)$. Hasil simulasi software ETAP 12.6.0 pada setiap fasa dari trafo, yaitu: trafo line-B:

1. Besarnya daya pada $R / L 1$ adalah: $(P=88 k W),(S=99 k V A),(Q=44 k V A R)$.

2. Besarnya daya pada $S / L 2$ adalah: $(P=77 \mathrm{~kW}),(\mathrm{S}=86 \mathrm{kVA}),(\mathrm{Q}=38 \mathrm{kVAR})$.

3. Besarnya daya pada $T / L 3$ adalah: $(P=90 k W),(S=97 k V A),(Q=35 k V A R)$.

4. Besarnya faktor daya ( $P F=90,9 \%)$.

\section{Hasil Simulasi Harmonisa}

Hasil program simulasi harmonic analysis (HA) menggunakan software ETAP 12.6.0 sebelum perbaikan ditampilkan sebagai pembanding dari hasil program simulasi sesudah perbaikan.

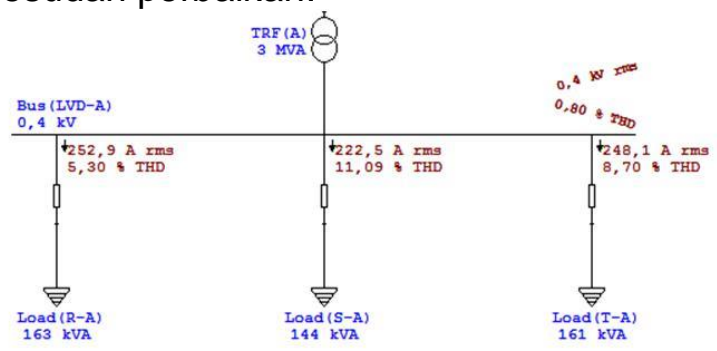

Gambar 20. Harmonic Trafo-A

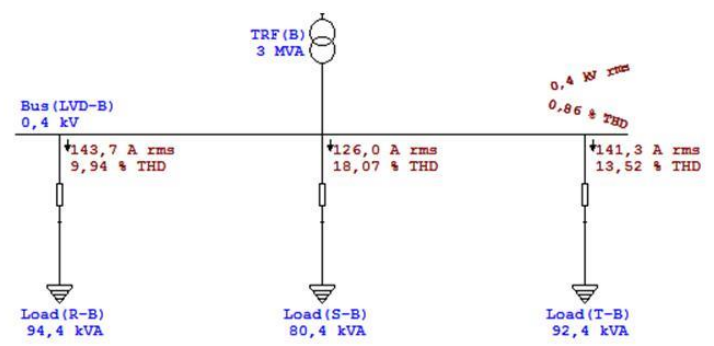

Gambar 21. Harmonic Trafo-B

Gambar 20 dan 21 menunjukkan hasil simulasi arus distorsi harmonisa total $\left(T H D_{i}\right)$ pada setiap fasa dari trafo, yaitu:

1. Trafo line-A: R/L1 $\left(T H D_{i}=5,30 \%\right), \mathrm{S} / \mathrm{L} 2$ $\left(T H D_{i}=11,09 \%\right), \mathrm{T} / \mathrm{L} 3\left(T H D_{i}=8,70 \%\right)$.

2. Trafo line-B: R/L1 $\left(T H D_{i}=9,94 \%\right), S / L 2$ $\left(T H D_{i}=18,07 \%\right), \mathrm{T} / \mathrm{L} 3\left(T H D_{i}=13,52 \%\right)$.

\section{Perhitungan Hasil Pengukuran}

Hasil pengukuran didapat: tegangan $\left(V_{r m s}\right)$, arus $\left(A_{\text {rms }}\right)$, dan frekuensi $(\mathrm{Hz})$ daya nyata $(P)$, daya semu $(S)$, daya reaktif $(Q)$, dan faktor daya $(P F)$ setiap fasa trafo line-A.

Tabel 4. Hasil Pengukuran Trafo Line-A

\begin{tabular}{|c|c|c|c|c|}
\hline \multirow{2}{*}{$\begin{array}{c}\text { Hasil } \\
\text { Pengukuran }\end{array}$} & \multicolumn{3}{|c|}{ Trafo A } & \multirow{2}{*}{ AVG } \\
\hline & (L1) & (L2) & (L3) & \\
\hline
\end{tabular}

\begin{tabular}{ccccc}
\hline $\begin{array}{c}\text { Tegangan } \\
(\text { Vrms) }\end{array}$ & 222,5 & 223,2 & 223,2 & 223,0 \\
\hline Arus (Arms) & 757 & 660 & 742 & 719,7 \\
\hline Frekuensi (Hz) & 50,0 & 50,0 & 50,0 & 50,0 \\
\hline $\begin{array}{c}\text { Faktor Daya } \\
(\%)\end{array}$ & 80,6 & 82,9 & 88,4 & 84,0 \\
\hline $\begin{array}{c}\text { Daya Nyata } \\
(\mathrm{kW})\end{array}$ & 137,8 & 123,6 & 147,9 & 409,3 \\
\hline $\begin{array}{c}\text { Daya Semu } \\
(\mathrm{kVA})\end{array}$ & 170,8 & 148,9 & 167,2 & 486,9 \\
\hline $\begin{array}{c}\text { Daya Reaktif } \\
\text { (kVAR) }\end{array}$ & 101,3 & 82,1 & 77,8 & 261,2 \\
\hline
\end{tabular}

Menurut standard NEMA MG1, bahwa ketidakseimbangan tegangan dinyatakan dalam persen ketidakseimbangan tegangan $(\% \mathrm{KT})$.

$$
\begin{aligned}
& \% K T=\frac{[(223,0-222,5)]}{(223,0)} \times 100 \%=0,2 \% \\
& \% K A=\frac{[(719,7-660)]}{(719,7)} \times 100 \%=8,3 \%
\end{aligned}
$$

Terlihat persen ketidakseimbangan tegangan $(\% K T=0,2 \%)$, maka sistem ini dalam keadaan keseimbangan (ideal), sementara persen ketidakseimbangan arus ( $\% K A=8,3 \%)$, sehingga sistem ini dalam ketidak-seimbangan arus (tidak ideal).

Sementara hasil pengukuran pada setiap fasa dari trafo line-B.

Tabel 5. Hasil Pengukuran Trafo Line-B

\begin{tabular}{ccccc}
\hline \hline Hasil & \multicolumn{3}{c}{ Trafo B } & AVG \\
\cline { 2 - 4 } Pengukuran & (L1) & (L2) & (L3) & \\
\hline \hline $\begin{array}{c}\text { Tegangan } \\
\text { (Vrms) }\end{array}$ & 224,8 & 223,5 & 224,8 & 224,4 \\
\hline Arus (Arms) & 429 & 372 & 420 & 407,0 \\
\hline Frekuensi (Hz) & 50,03 & 50,03 & 50,03 & 50,03 \\
\hline $\begin{array}{c}\text { Faktor Daya } \\
(\%)\end{array}$ & 89,3 & 89,6 & 93,4 & 90,8 \\
\hline $\begin{array}{c}\text { Daya Nyata } \\
(\mathrm{kW})\end{array}$ & 87,1 & 75,0 & 87,6 & 249,7 \\
\hline $\begin{array}{c}\text { Daya Semu } \\
(\mathrm{kVA})\end{array}$ & 97.0 & 83,1 & 93,3 & 273,4 \\
\hline $\begin{array}{c}\text { Daya Reaktif } \\
\text { (kVAR) }\end{array}$ & 36,8 & 29,0 & 22,4 & 88,2 \\
\hline \hline
\end{tabular}

Dengan solusi perhitungan didapat:

$$
\begin{aligned}
& \% K T=\frac{[(224,4-223,5)]}{(224,4)} \times 100 \%=0,4 \% \\
& \% K A=\frac{[(407,0-372)]}{(407,0)} \times 100 \%=8,6 \%
\end{aligned}
$$

Terlihat persen ketidakseimbangan tegangan $(\% K T=0,4 \%)$, maka sistem ini dalam keseimbangan (ideal), sementara persen ketidakseimbangan arus ( $\% K A=$ $8,6 \%)$, sehingga sistem dalam ketidakseimbangan arus (tidak ideal), karena menurut standar ANSI C84.1-1995 bahwa 
ketidakseimbangan tegangan sistem tidak boleh melebihi atau maksimum $6 \%$.

Perbandingan nilai antara pengukuran Fluke 1735 Power Logger dikurangi dengan hasil perhitungan rumus-rumus daya.

Tabel 6. Perbandingan Daya Trafo Line-A

\begin{tabular}{clccc}
\hline \multicolumn{4}{c}{ Perbandingan Pengukuran dan Perhitungan } \\
\hline \multicolumn{2}{c}{ (Trafo A) } & (kW) & (kVA) & (kVAR) \\
\hline \hline (L1) & Fluke & 137,8 & 170,8 & 101,3 \\
\hline & Rumus & 135,7 & 168,4 & 99,7 \\
\hline & $\begin{array}{l}\text { Deviasi } \\
\text { (L2) }\end{array}$ & 2,1 & 2,4 & 1,6 \\
\hline & $\begin{array}{l}\text { Deviasi } \\
\text { (\%) }\end{array}$ & $\mathbf{1 , 5 2}$ & $\mathbf{1 , 4 1}$ & $\mathbf{1 , 5 8}$ \\
\hline \hline (L2) & Fluke & 123,6 & 148,9 & 82,1 \\
\hline & Rumus & 122,1 & 147,3 & 82,4 \\
\hline & $\begin{array}{l}\text { Deviasi } \\
\text { (L2) }\end{array}$ & 1,5 & 1,6 & $-0,3$ \\
\hline & $\begin{array}{l}\text { Deviasi } \\
\text { (\%) }\end{array}$ & $\mathbf{1 , 2 1}$ & $\mathbf{1 , 0 8}$ & $-\mathbf{0 , 3 7}$ \\
\hline \hline (L3) & Fluke & 147,9 & 167,2 & 77,8 \\
\hline & Rumus & 146,4 & 165,6 & 77,5 \\
\hline & $\begin{array}{l}\text { Deviasi } \\
\text { (L2) }\end{array}$ & 1,5 & 1,6 & 0,3 \\
\hline & $\begin{array}{l}\text { Deviasi } \\
\text { (\%) }\end{array}$ & $\mathbf{1 , 0 1}$ & $\mathbf{0 , 9 6}$ & $\mathbf{0 , 3 9}$ \\
\hline & & & &
\end{tabular}

Tabel 7. Perbandingan daya trafo line-B

\begin{tabular}{clccc}
\hline \hline \multicolumn{4}{c}{ Perbandingan Pengukuran dan Perhitungan } \\
\hline \multicolumn{2}{c}{ (Trafo A) } & (kW) & (kVA) & (kVAR) \\
\hline (L1) & Fluke & 87,1 & 97,0 & 36,8 \\
\hline & Rumus & 86,1 & 96,4 & 36,1 \\
\hline & $\begin{array}{l}\text { Deviasi } \\
\text { (L2) }\end{array}$ & 1,0 & 0,6 & $-6,5$ \\
\hline $\begin{array}{l}\text { Deviasi } \\
\text { (\%) }\end{array}$ & $\mathbf{0 , 3 4}$ & $\mathbf{0 , 6 2}$ & $\mathbf{0 , 7}$ \\
\hline \hline (L2) & Fluke & 75,0 & 83,1 & 29,0 \\
\hline & Rumus & 74,5 & 83,1 & 30,5 \\
\hline & $\begin{array}{l}\text { Deviasi } \\
\text { (L2) }\end{array}$ & 0,5 & 0,0 & $-1,5$ \\
\hline & $\begin{array}{l}\text { Deviasi } \\
\text { (\%) }\end{array}$ & $\mathbf{0 , 6 7}$ & $\mathbf{0}$ & $\mathbf{- 5 , 1 7}$ \\
\hline (L3) & Fluke & 87,6 & 93,3 & 22,4 \\
\hline & Rumus & 88,2 & 94,4 & 23,6 \\
\hline $\begin{array}{l}\text { Deviasi } \\
\text { (L2) }\end{array}$ & $-0,6$ & $-1,1$ & $-1,2$ \\
\hline $\begin{array}{l}\text { Deviasi } \\
\text { (\%) }\end{array}$ & $\mathbf{- 0 , 6 9}$ & $\mathbf{- 1 , 1 8}$ & $\mathbf{- 5 , 3 6}$ \\
\hline \hline
\end{tabular}

\section{Desain Filter Harmonisa}

Perancangan filter pasif (single tuned) karena filter ini mempunyai impedansi yang rendah dan biaya yang murah. Untuk memperbaiki faktor daya menggunakan perhitungan dalam perancangan filter pasif, dimulai dengan menentukan daya semu.

$V_{L L}=\sqrt{3} \times 224,3=389 \mathrm{~V}=0,389 \mathrm{kV}$

$I_{L}=V_{\text {avg }}=720,7$ Ampere
$S=\sqrt{3} \times 389 \times 720,7=486 k V A$

Daya reaktif didapat:

$$
\begin{gathered}
P F=\theta_{1}=0,84, \\
Q_{1}=486 \times \sin (32,86)=263,7 \mathrm{kVAR} \\
P F=\theta_{2}=0,96 \\
Q_{2}=486 \times \sin (16,3)=136,4 \mathrm{kVAR}
\end{gathered}
$$

Maka total daya reaktif yang dibutuhkan filter pasif untuk mengkompensasi.

$Q_{C}=263,7-136,4=127,3 \mathrm{kVAR}$

Dengan memakai jenis kapasitor 30 kVAR, maka $Q_{C}=90 \mathrm{kVAR}$

$X_{\text {filter }}=\frac{(0,389)^{2} \times\left(10^{3}\right)}{127,3}=\frac{151,321}{127,3}=1,2 \Omega$

Nilai reaktansi induktif dan reaktansi kapasitif, pada frekuensi $250 \mathrm{~Hz}$ (orde ke-5).

$X_{c}=\left[\frac{20,25}{20,25-1}\right] \times 1,2=1,3$

Nilai h diperoleh: $h=5-(5 \times 10 \%)=4,5$

Menentukan nilai kapasitor:

$C=\frac{1}{2 \times 3,14 \times 50 \times 1,25}=2548 \mu \mathrm{F}$

Sedangkan nilai dari induktor:

$X_{L}=\frac{1,25}{4,5^{2}}=\frac{1,25}{20,25}=0,062$

Nilai induktor tersebut untuk sistem 3 fasa, sehingga jika digunakan pada sistem 1 fasa, maka $X_{L}=0,062 / \sqrt{3}=0,04$, sedang untuk nilai dari induktor:

$L=\frac{0,062}{2 \times 3,14 \times 50}=0,198 \mathrm{mH}$

Rangkaian filter pasif harmonisa terdiri dari $R$, $L$, dan $C$, maka penentuan nilai $R$ dengan $Q$ bernilai antara 20-100, sehingga jika dipilih $Q=50$, maka:

$R=\frac{n \times X_{L}}{Q}=\frac{5 \times 0,062}{50}=0,0062 \Omega$

Nilai resistor tersebut untuk sistem 3 fasa, sehingga jika digunakan pada sistem 1 fasa, maka $R=0,0062 / \sqrt{3}=0,004 \Omega$.

\section{Hasil Simulasi Filter Harmonisa}

Pengisian parameter filter pasif harmonisa pada program simulasi ETAP 12.6.0.

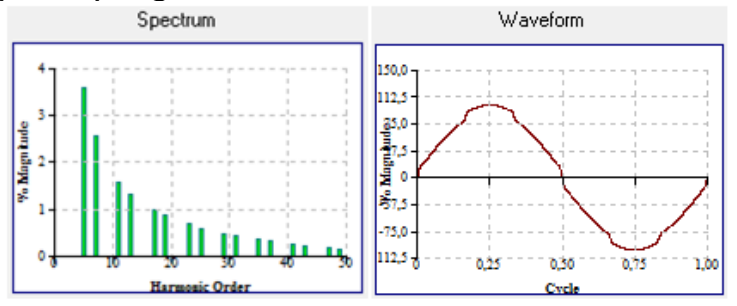

Gambar 22. Harmonic Library 


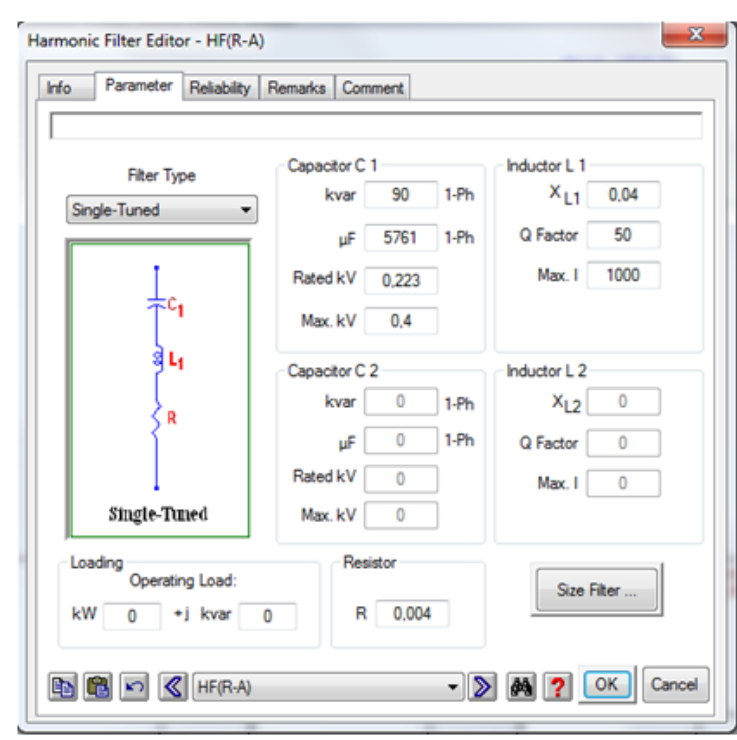

Gambar 23. Harmonic Filter Editor

Selanjutnya jalankan simulasi program dan lihat hasil perbaikan (reduksi) harmonisa setelah dipasang filter pasif harmonisa.

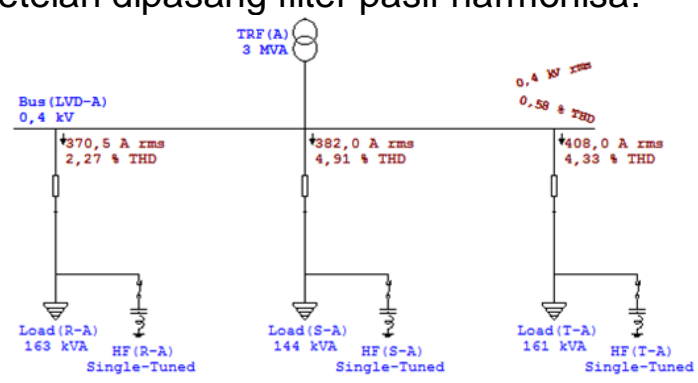

Gambar 24. Hasil Simulasi Harmonisa Trafo-A

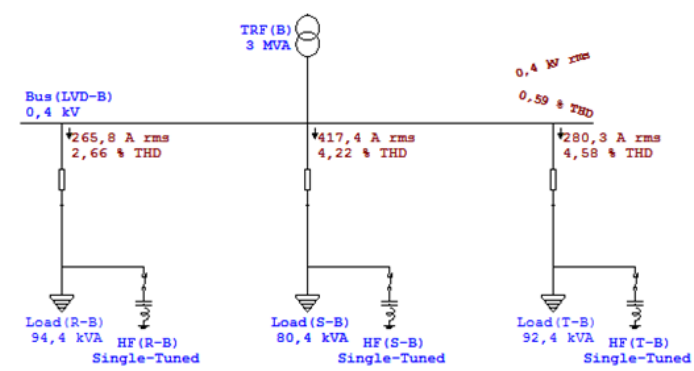

Gambar 25. Hasil Simulasi Harmonisa Trafo-B

\section{Analisis Hasil Simulasi Filter Harmonisa}

Simulasi (HA) sesudah pemasangan.

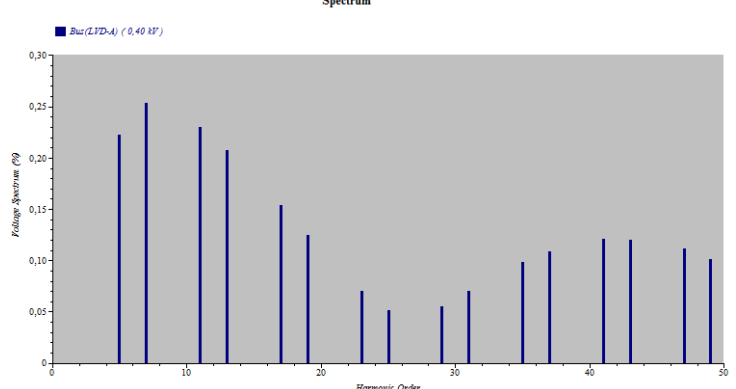

Gambar 26. Spektrum Harmonisa

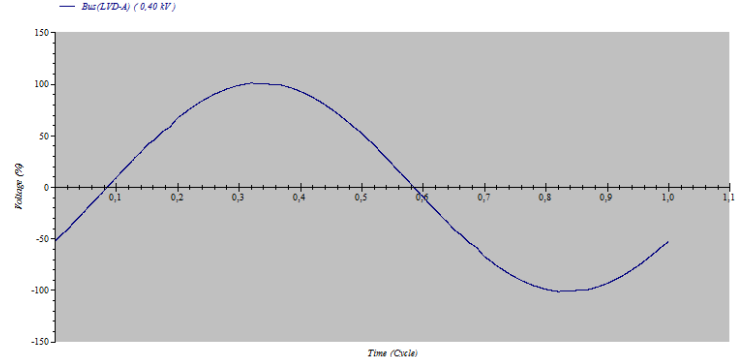

Gambar 27. Gelombang Harmonisa

Perbandingsan hasil simulasi (HA) ini sebelum dan sesudah dipasang filter pasif harmonisa pada SDL di Industri.

Tabel 8. Perbandingan Sebelum \& Sesudah

\begin{tabular}{ccccc}
\hline \hline Perbandingan & \multicolumn{3}{c}{ Pemasangan Filter Pasif } \\
\cline { 2 - 5 } Hasil & \multicolumn{2}{c}{ Sebelum } & \multicolumn{2}{c}{ Sesudah } \\
\cline { 2 - 5 } Simulasi & Trafo & Trafo & Trafo & Trafo \\
ETAP 12.6.0 & A & B & A & B \\
\hline \hline THDi (\%) R/L1 & 5,30 & 9,94 & 2,27 & 2,66 \\
\hline THDi (\%) S/L2 & 11,09 & 18,07 & 4,91 & 4,22 \\
\hline THDi (\%) T/L3 & 8,70 & 13,52 & 4,33 & 4,58 \\
\hline \hline
\end{tabular}

Dari Tabel 8 menunjukkan adanya reduksi harmonisa sesudah dipasang filter pasif, dengan rincian sebagai berikut:

1. Pada trafo-A, THDv turun dari $0,80 \%$ ke $0,59 \%$, sedang THDi turun pula, yaitu:
a. Fasa R/L1 dari $5,30 \%$ ke $2,27 \%$.
b. Fasa S/L2 dari $11,09 \%$ ke $4,91 \%$.
c. Fasa T/L3 dari $8,70 \%$ ke $4,33 \%$.

2. Pada trafo-B, THDv turun dari $0,86 \%$ ke $0,59 \%$, sedang THDi turun pula, yaitu:
a. Fasa R/L1 dari $9,94 \%$ ke $2,66 \%$.
b. Fasa S/L2 dari $18,07 \%$ ke $4,22 \%$.
c. Fasa T/L3 dari $13,52 \%$ ke $4,58 \%$.

\section{KESIMPULAN}

Simpulan dari penelitian ini merupakan hasil akhir dari seluruh rangkaian penelitian yang telah dilakukan terkait perbaikan (reduksi) hasmonisa yang terjadi pada sisi sekunder dari 2 unit transformator 3000 kVA 6,3/0,4 kV di Industri, yang meliputi:

1. Terjadi arus distorsi harmonisa total (THDi) pada trafo-A: $R / L 1=5,3 \%, S / L 2=$ $11,1 \%, T / L 3=8,7 \%$ serta pada trafo-B: $R / L 1=9,9 \%, S / L 2=18,0 \%, T / L 3=13,5 \%$.

Berdasarkan standar IEEE 512-1992 bahwa THDi yang diperbolehkan apabila bernilai di bawah $5 \%$, maka sistem ini perlu dilakukan reduksi arus distorsi harmonisa.

2. Terjadi ketidakseimbangan tegangan (\%KT) sebesar $0,22 \%$ pada trafo $(\mathrm{A})$ dan 
0,4\% pada trafo (B) sehingga sistem dapat dikatakan dalam keadaan keseimbangan tegangan (ideal), dan terjadi persen ketidakseimbangan arus $(\% \mathrm{KA})$ sebesar $8,3 \%$ pada trafo $(\mathrm{A})$ dan $8,6 \%$ pada trafo (B) sehingga sistem dalam ketidak-seimbangan arus (tidak ideal), karena menurut ANSI C84.1-1995 ketidakseimbangan beban tidak boleh melebihi atau maksimum 6\%.

3. Dengan perbaikan faktor daya ( $P F=$ $96 \%$ ) didapat parameter komponen filter pasif dengan $(R=0,004 \Omega),\left(X_{L}=0,04\right)$, $(C=90 \mathrm{kVAR})$.

4. THDv tereduksi dari $0,80 \%$ ke $0,58 \%$ (trafo-A) dan dari $0,86 \%$ ke $0,59 \%$ (trafoB), berdasarkan IEEE 512-1992 bahwa THDV pada tegangan < $69 \mathrm{kV}$ diperbolehkan jika bernilai dibawah $5 \%$.

5. THDi tereduksi (trafo-(A): R/L1 dari $5,30 \%$ ke $2,27 \%$, S/L2 dari $11,09 \%$ ke $4,91 \%$ dan T/L3 dari $8,70 \%$ ke $4,33 \%$. Kemudian (trafo-B): R/L1 dari 9,94\% ke $2,66 \%$, S/L2 dari $18,07 \%$ ke $4,22 \%$ dan T/L3 dari 13,52\% ke 4,58\%. Berdasarkan IEEE 512-1992 bahwa THDi yang diijinkan apabila bernilai di bawah 5\%.

Saran merupakan sebuah harapan akan tindaklanjut dari hasil penelitian, dengan harapan yang dapat bermanfaat bagi pegembangan Kampus, Industri, penulis dan masyarakat luas, meliputi:

1. Untuk Industri, diharapakan segera melakukan pembagian beban pada setiap fasanya karean saat ini terjadi ketidakseimbangan beban yang sudah diatas standar yang diijinkan $6 \%$.

2. Bagi kampus, diharapkan penelitian ini dapat digunakan sebagai bahan refernsi dalam pengembangan ilmu pengetahuan dikemudian hari berkaitan dengan harmonisa pada SDL.

3. Penelitian ini masih jauh dari kesempurnaan, terutama dari sisi pengukuran $\mathrm{PQ}$ menggunakan Fluke 1735 Power Logger agar memperhatikan detail dan jumahdata yang diambil.

4. Dalam pemasangan filter harmonisa, penelitian tesis ini sebatas melakukan satu jenis filter harmonisa yang digunakan, yaitu: single tuned, kedepan diharapakan dalam melakukan penelitian lanjutan menggunakan variasi filter harmonisa.

\section{UCAPAN TERIMAKASIH}

Dalam melalui seluruh tahapan-tahapan penelitian ini tentunya penulis tidak dapat bekerja sendiri. Untuk itu, dalam kesempatan ini penulis akan mengajukan terima kasih kepada pihak yang membantu terlaksananya penelitian ini, antra lain:

1. Bapak Dr. Ir. Djoko H. N., M.T.

2. Bapak Syaiful B., S.T., M.Eng.Sc., Ph.D.

3. Bapak Seflahir D., S.T., M.Pd.T.

4. Rekan-rekan seperjuangan yang telah banyak membantu dalam penyelesaian penelitian ini.

\section{DAFTAR REFERENSI}

[1] Khalid, S. dan Dwivedi, B. 2011. Power Quality Issues, Problems, Standards \& Their Effects in Industry with Corrective Means. International Journal of Advances in Engineering \& Technology (IJAET), ISSN: 2231-1963. 1(2): 1-11.

[2] Farooq, H. dkk. 2011. Investigating the Power Quality of an Electrical Distribution System Stressed by NonLinear Domestic Appliances. International Conference on Renewable Energies and Power Quality (ICREPQ), DOI: 10.24084. 1(9): 283-288.

[3] Surasmi, N.L. dan Sindhu, M.R. 2012. Optimum Allocation of Active Filters In A 4-Bus System Using Genetic Algorithm. International Journal of Emerging Technology and Advanced Engineering (IJETAE), ISSN: 22502459. 2(4): 251-256.

[4] Goyal, D.K. dan Chaturvedi, A. 2013. Harmonic and Transient Stability Analysis of GISTRANSCO Network Using ETAP. International Journal of Science and Research (IJSR), ISSN (Online): 2319-7064. 5(1): 1003-1007.

[5] Nasrul dan Firmansyah. 2015. Harmonics Impact a Rising Due to Loading and Solution ETAP Using the Distribution Substation Transformer 160 kVA at Education and Training Unit PT PLN. International Journal on Advanced Science Engineering Information Technology (IJASEIT), ISSN: 20885334. 5(6): 469-474.

[6] Ayunda, S.W. 2016. Harmonics propagation and distortion caused by 
anonlinear load in balance distribution network. International Scholars Journals (ISJ), African Journal of Physics (AJP). 3(5): 110-118.

[7] Ravichandran, D. dan Panneerselvam, E.R. 2016. Harmonic Study in Low Voltage Distribution Network in a Real Time Foundry Industry. International Science Press (IJCTA). 9(37): 769-781.

[8] Zahran, M.H. dkk. 2016. Power Loss Minimization In Distribution SystemUsing Static VAR Compansator. International Journal of Engineering and Innovative Technology (IJEIT), ISSN: 2277-3754, ISO 9001:2008 Certified. 5(11): 60-65.

[9] Assaffat, L. 2009. Pengukuran dan Analisa Kualitas Daya Listrik di Paviliun Garuda Rumah Sakit Dr. Karyadi Semarang. Media Elektrika. 2(1): 18-23.

[10] Hontong, N.J. dkk. 2015. Analisa Rugirugi Daya pada Jaringan Distribusi di PT. PLN Palu. E-Journal Teknik Elektro dan Komputer (E-JTEK), ISSN: 23018402. 64-71.

[11] Masri, M. dkk. 2015. Analisis Pengaruh Ketidakseimbangan Tegangan Terhadap Kinerja Motor Induksi Tiga Fasa dengan Matlab. ResearchGate, DOI: 10.13140, SNPPTI, ISSN: 0862156. 111-115.

[12] Assaffat, L. 2010. Analisa Faktor-faktor yang Mempengaruhi Tingkat Harmonisa pada Motor Induksi Tiga Fasa Tipe Rotor sangkar Tupai. Prosiding Seminar Nasional UNIMUS, ISBN: 978-979-7048-83-9. 439-453

[13] Sartika, S. dan Octaviani, A. 2015. Penanganan Harmonisa Terhadap Peningkatan Kualitas Daya Listrik Berbasis Software Etap (Studi Kasus: Pabrik Semen Tonasa V). Prosiding Seminar Nasional Teknik Energi dan Ketenagalistrikan (SNTEK), ISBN: 978602-72676-3-3. 59-66.

[14] Efandi, R. dkk. 2015. Studi Perencanaan Filter Hybrid untuk Mengurangi Harmonisa pada Proyek Pakistan Deep Water Container Port. Jurnal Teknik ITS, ISSN: 2337-3539 (2301-9271 Print). 4(2): 142-147.

[15] Fauzan, M.R. dkk. 2015. Analisa Harmonisa Akibat Pengaruh Penggunaan Converter pada Kereta
Rel Listrik 1x25 kV Jogyakarta-Solo. ELECTRICIAN-Jurnal Rekayasa dan Teknologi Elektro. 9(3): 192-202.

[16] Sumarno, S.S. dkk. 2016. Studi Analisis dan Mitigasi Harmonisa pada PT. Semen Indonesia Pabrik Aceh. Jurnal Teknik ITS, ISSN: 2337-3539 (23019271 Print). 5(2): 456-461.

[17] Prawira, I.G.A.A. dkk. 2013. Implementasi Fuzzy Logic Controller pada Filter Active Shunt untuk Menanggulangi THD (Total Harmonic Distortion) Sistem Kelistrikan RSUP Sanglah. Prosiding Conference on Smart-Green Technology in Electrical and Information Systems, ISBN: 978602-7776-72-2. A(007): 25-30.

[18] Putro, A.P. dan Sofwan, A. 2015. Analisa Penanggulangan Gangguan Harmonik (THD) dengan Filter Aktif Berbasis Mikrokontroler terhadap Beban Mesin Welding. Technologic. 6(2): 1-6.

[19] Zulkarnaini, dkk, 2017. Studi Analisa Distorsi Harmonik pada Unit Kiln Indarung II PT. Semen Padang. Jurnal Momentum, ISSN: 1693-752X, DOI 10.21063, ITP Press. 19(1): 40-46.

[20] Samman, F.A. dkk. 2015. Perancangan, Simulasi dan Analisis Harmonisa Rangkaian Inverter Satu Fasa. JNTETI, ISSN: 2301-4156. 4(1): 62-70.

[21] Winarno, I. dan Pahlevi, A.B. 2017. Reduksi Harmonisa pada Motor Sinkron 3 Fasa Menggunakan Filter Aktif Shut Berbasis Fuzzy Logic. CITEE, Departemen Teknik Elektro dan Teknologi Informasi, FT-UGM, ISSN: 2085-6350. 63-69.

[22] Fluke Corporation. 2008. Energy studies with the Fluke 1735 Power Logger. Printed 2584800 A-EN-N Rev E. PO Box 9090, Everett, WA 98206 U.S.A. 